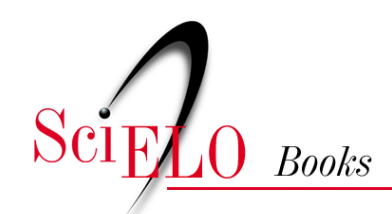

\title{
Movimento das Mulheres Camponesas (MMC)
}

\author{
José Carlos Radin \\ Gentil Corazza
}

\section{SciELO Books / SciELO Livros / SciELO Libros}

RADIN, J.C., and CORAZZA, G. Movimento das Mulheres Camponesas (MMC). In: Dicionário histórico-social do Oeste catarinense [online]. Chapecó: Editora UFFS, 2018, pp. 97-101. ISBN: 97885-64905-65-8. https://doi.org/10.7476/9788564905658.0023.

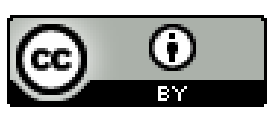

All the contents of this work, except where otherwise noted, is licensed under a Creative Commons Attribution 4.0 International license.

Todo o conteúdo deste trabalho, exceto quando houver ressalva, é publicado sob a licença Creative Commons Atribição 4.0.

Todo el contenido de esta obra, excepto donde se indique lo contrario, está bajo licencia de la licencia $\underline{\text { Creative Commons }}$ Reconocimento 4.0. 


\section{Movimento das Mulheres Camponesas (MMC)}

O Movimento das Mulheres Camponesas (MMC) é um movimento social organizado em nível nacional, na década de 1980, a partir da unificação de diversos movimentos de mulheres agricultoras espalhados pelas diferentes regiões do país. Ele se define como um movimento "autônomo, democrático, popular, classista" e luta por uma perspectiva socialista de sociedade (mmcbrasil.com.br).

Na região Oeste de Santa Catarina, a constituição de um movimento específico de mulheres agricultoras contou com o apoio decisivo de segmentos da Igreja Católica, de modo especial as comunidades eclesiais de base e a Comissão Pastoral da Terra, cujas ações sempre contaram com o estímulo e o apoio do bispo de Chapecó, Dom José Gomes. A origem e evolução do MMC, na região Oeste, estão associadas a diversos eventos (POLI, 1999). O marco histórico inicial teria sido o dia 25 de julho de 1981, por ocasião das comemorações do dia do colono, no então distrito de Itaberaba, município de Chapecó. Foi neste lugar e nesta ocasião que se formou, inicialmente, o Movimento das Mulheres Agricultoras (MMA). A partir deste marco inicial, foram desenvolvidas as primeiras ações concretas para estruturar um movimento social de mulheres agricultoras. Em $1^{\circ}$ de maio de 1983, Dia do Trabalho, realizou-se outro encontro importante, que reuniu 28 mulheres de diversas comunidades da região, entre as quais se incluíam líderes camponesas, líderes sindicais e agentes pastorais. Em 08 de março de 1984, dia Internacional da Mulher, as camponesas fundaram a Organização das Mulheres Agricultoras (OMA) e, em 1986, decidiu-se pela consolidação do Movimento de Mulheres Agricultoras (MMA) de Santa Catarina. Em 2003, foi tomada a decisão conjunta de unificar as diferentes organizações de mulheres de quatorze estados brasileiros, unificação que veio a materializar-se, em 2004, com a criação do Movimento das Mulheres Camponesas (MMC). 
A motivação inicial, que desencadeou a formação dos diversos movimentos de mulheres camponesas, foi condição subordinada da mulher no seio da família, no sindicato de pequenos agricultores e na sociedade. Foi a partir das conversas e debates no âmbito das diversas organizações de mulheres, que foi se formando a consciência e o questionamento das condições desiguais e discriminatórias enfrentadas pelas mulheres e a necessidade de lutar contra elas. No próprio sindicato de trabalhadores rurais, elas não tinham direito a voto, nem a concorrer a cargos de lideranças. Só podiam participar do sindicato, mulheres solteiras e autônomas. Mulheres casadas nem poderiam ser sócias do sindicato. A partir dessas lutas concretas pela igualdade de direitos no seio da família e na vida sindical, a luta das mulheres camponesas transformou-se numa luta pelas transformações sociais.

O MMC trabalha com um conceito amplo de mulher camponesa: "somos mulheres agricultoras, arrendatárias, meeiras, ribeirinhas, posseiras, boias-frias, diaristas, parceiras, extrativistas, quebradeiras de coco, pescadoras artesanais, sem-terra, assentadas, mulheres índias, negras, descendentes de europeus. Somos a soma da diversidade das mulheres do nosso país". (mmcbrasil.com.br).

A pauta de lutas do MMC também é ampla e diversa como o próprio conceito de mulher camponesa. Entre elas, destaca-se o reconhecimento da profissão de trabalhadora rural, o salário-maternidade, a aposentadoria da mulher da roça aos 55 anos, a luta por saúde de qualidade, por políticas públicas, que atendam aos interesses das camponesas, pelas condições de permanência no meio rural, pela construção de novas relações sociais e de gênero, e pelo fim de todas as formas de violência e opressão.

Ao mesmo tempo, o MMC tem consciência de que a luta das mulheres camponesas é uma luta delas mesmas: "lutar sempre foi nossa condição", "a luta pela libertação das mulheres é tarefa de todos", mas "a libertação da mulher é obra da própria mulher, fruto da organização e da luta", "nós mulheres somos as principais responsáveis por esta conquista". Por isso, o MMC define-se como "movimento autônomo, democrático, popular, feminista" e ao mesmo tempo é movido pela convicção de que a condição da mulher camponesa só muda se 
mudar também a sociedade em que ela vive, a luta do MMC é uma luta de "classe social, na perspectiva socialista". Trata-se de uma "luta por novas relações entre as pessoas e destas com a natureza". "Pertencemos à classe trabalhadora, lutamos pela causa feminista e pela transformação da sociedade". A luta das mulheres camponesas é a luta de todos os trabalhadores e trabalhadoras. O MMC luta para que as mulheres camponesas sejam sujeitos da sua própria história (www. mmcbrasil.com.br).

\section{REFERÊNCIAS}

POLI, Odilon Luiz. Leituras em Movimentos Sociais. Chapecó: Grifos, 1999.

LACERDA ADÃO, Nilton Manoel. Movimento das mulheres camponesas: a origem religiosa e o "cuidado" na estrutura familiar. In: PERETTI, Clélia (Org.) Congresso de Teologia da PUCPR. Champagnat, 2011. Disponível em: <http://www.pucpr.br/eventos/congressoteologia/2011>. Acesso em: 27 abr. 2016. 